\title{
DEVELOPMENTS IN INDIANA CONSTITUTIONAL LAW: A New Equal Privileges Wrinkle
}

\author{
JON LARAMORE* \\ DANIEL E. PULLIAM**
}

After the turnover of three justices in as many years, the Indiana Supreme Court's membership remained constant during the survey period. ${ }^{1}$ The court plowed little new ground in state constitutional law, and only time will tell whether the survey period represents the beginning of a pattern of less state constitutional activity by this "new" Indiana Supreme Court.

The Indiana Supreme Court did, however, issue an important decision applying the equal privileges and immunities clause, further explaining the significance of the requirement that statutory classifications be based on categories that possess "inherent differences" from one another. ${ }^{2}$ The Indiana Court of Appeals applied the Indiana Constitution in the context of the education provisions in article 8, rejecting a claim for damages under the Indiana Constitution. ${ }^{3}$ The Indiana Supreme Court applied the free expression provisions of the Indiana Constitution to a case involving threats. ${ }^{4}$ And, as in most years, the supreme court and court of appeals issued decisions continuing to develop Indiana's unique constitutional doctrines regarding searches and seizures and multiple-punishments double jeopardy. ${ }^{5}$

\section{EQUAL PRIVILEGES AND IMMUNITIES}

The Indiana Supreme Court broke new analytical ground applying the equal privileges and immunities clause, article 1, section 23, in Paul Stieler Enterprises, Inc. v. City of Evansville. ${ }^{6}$ The court applied the clause to Evansville's ordinance banning smoking in most public places, including bars

* Jon Laramore is executive director of Indiana Legal Services, Inc. At the time this Article was drafted, he was a partner and co-chair of the appellate advocacy group at Faegre Baker Daniels, LLP. Previously he was chief counsel to Indiana Governors Frank O'Bannon and Joseph Kernan, and he taught state constitutional law as an adjunct professor at Indiana University Robert $\mathrm{H}$. McKinney School of Law.

** Daniel Pulliam is an associate in the business litigation group at Faegre Baker Daniels, LLP. B.A., 2004, cum laude, Butler University, Indianapolis; J.D., 2010, magna cum laude, Indiana University Robert H. McKinney School of Law. He is also a former Editor-in-Chief of the Indiana Law Review and The Butler Collegian and a former law clerk for Judge John Daniel Tinder on the United States Court of Appeals for the Seventh Circuit.

1. See, e.g., Indiana Supreme Court Justice Biographies, http://www.in.gov/judiciary/ supreme/2332.htm (last visited Mar. 16, 2015), archived at http://perma.cc/AL42-6EZR.

2. See infra Part I.

3. See infra Part II.

4. See infra Part III.

5. See infra Parts V-VI.

6. 2 N.E.3d 1269 (Ind. 2014).

http://dx.doi.org/10.18060/4806.0040 
and restaurants, but exempting the riverboat casino docked at Evansville. ${ }^{7}$ A group of bars and restaurants challenged the ordinance because they claimed to be disadvantaged by the smoking ban. ${ }^{8}$ They used the equal privileges and immunities clause as the basis for their argument that the ban was unconstitutional because the riverboat exemption did not pass the constitutional test under the clause. ${ }^{9}$ As the court put it, "[t]he Bars and Clubs contend that the ... Smoking Ban gives the Casino a privilege - an exemption from the Smoking Ban - that is not provided to the Bars and Clubs and others similarly situated . ..."10

The City and the bar and restaurants agreed that the classes to be analyzed under article 1, section 23 were (1) bars and restaurants subject to the smoking ban, and (2) the casino, not subject to the ban. ${ }^{11}$ The City attributed two distinguishing characteristics to the casino - it is floating, while the bars and restaurants are land-based, and it conducts gambling under the Riverboat Gambling law, which the bars and restaurants do not (although some private clubs covered by the smoking ban provide gambling under other legal authority). ${ }^{12}$ The City also stressed the economic advantages that accrue to Evansville from the casino, including millions of dollars in tax revenue and many jobs; it also pointed out that eighty-seven percent of the casino's customers come from outside Evansville. ${ }^{13}$

The test under the equal privileges and immunities clause is two-fold: "First, the disparate treatment accorded by the legislature must be reasonably related to inherent characteristics which distinguish the unequally treated classes. Second, the preferential treatment must be uniformly applicable and equally available to all persons similarly situated." 14 Under this test, the court boiled down the issue to "whether the unequal prohibition of smoking is reasonably related to ... the Casino's authorization to conduct gambling under Indiana's Riverboat Gambling statute." 15

The court concluded that the economic justification the City offered for its disparate treatment of the casino was insufficient under article 1, section $23 .{ }^{16}$ The court emphasized the test from Collins $v$. Day that the disparate treatment must be related to the differences inherent between the differently treated

7. Id. at 1272 .

8. $I d$.

9. Id.

10. Id. at 1273 .

11. Id. at $1273-74$.

12. Id. at 1274 .

13. Id. at 1275 .

14. Collins v. Day, 644 N.E.2d 72, 80 (Ind. 1994).

15. Stieler, 2 N.E.3d at 1274 . The parties agreed that the disparate treatment was unrelated to the other distinguishing characteristic, which was that the casino was water-based while the entities subject to the smoking ban were land-based. $I d$.

16. Id. at 1275 . 
classes. ${ }^{17}$ And to examine whether the different treatment is based on inherent differences, "we focus not on the purposes presumably motivating the enactment, but on the disparate treatment it accords. It is "the treatment, not the legislative purpose, which must be reasonably related to the inherent distinctions between the classes ...."'18

But, the court stated, the legislative purpose could be taken into account. ${ }^{19}$ In this case, the court noted, the purpose of the smoking ban - as stated in its text-is protection of public health. ${ }^{20}$ It concluded that the City's economic rationale for exempting the casino "fails to reasonably relate the divergent treatment to the inherent differences involved." 21

The court also emphasized that the economic rationale is inimical to the purpose of the equal privileges and immunities clause as articulated by the framers. ${ }^{22}$ "[A]t the time of the adoption of Section 23 and its ratification as part of the 1851 Indiana Constitution, the principal purpose was to prohibit the state legislature from affirmatively granting any exclusive privilege or immunity involving the state's participation in commercial enterprise." 23 The court quoted the remarks of a delegate to the Constitutional Convention: "there shall be no exclusive monopolies - no privilege granted to one man which shall not, under the same circumstances, belong to all men." ${ }^{24}$

The court found fault with Evansville's ordinance on this basis. "Considering the economic rationale put forth in the present case, the City's enactment - granting a special privilege exempting riverboat casinos from the Smoking Ban in return for substantial tax and lease payments and other investments in the city ... is tantamount to the government 'selling' an exemption from the Smoking Ban for the bonus of anticipating financial benefits." ${ }^{25}$ The court stated that permitting a special benefit in exchange for these payments is not permitted under the Constitution. ${ }^{26}$ Based on this analysis, the court concluded that the smoking ban violated article 1, section 23 because it "provides an unequal privilege that is not reasonably related to the inherent distinguishing characteristics of the two affected groups."27

The court then applied a severability analysis, concluding that it could not determine whether the ordinance would have been passed without the casino

17. Id.

18. Id. (quoting Dvorak v. City of Bloomington, 796 N.E.2d 236, 239 (Ind. 2003)).

19. Id. (citing Dvorak, 796 N.E.2d at 239).

20. Id. (citing Evansville Ordinance G-2012-1, Preamble (2012)).

21. Id.

22. Id. at 1276 .

23. Id. (quoting Collins v. Day, 644 N.E.2d 72, 77 (Ind. 1994)).

24. Id. (quoting 2 Reports of the Debates and Proceedings of the Convention for the Revision of the Const. of the State of Ind. 1394 (1935 Reprint) (statement of Delegate Biddle)).

25. Id.

26. Id. at 1277 .

27. Id. at 1278 . 
exemption. ${ }^{28}$ Because it could not determine whether the constitutional error could be corrected by invalidating the exemption (and therefore making the smoking ban applicable to all the restaurants and bars and the casino), it invalidated the entire 2012 ordinance, which expanded the ban to the plaintiff bars and restaurants. ${ }^{29}$

Justice Rush dissented, joined by Justice Rucker. Justice Rush concluded that the City's economic rationale was sufficient to justify the disparate treatment of the casino: "fiscal impact on the local economy and City tax revenues is the first inherent characteristic that sets the City's only riverboat apart from other non-exempt entities." 30 She stated that it was permissible for the City to enact a public health regulation with an exemption like the one in this case because doing so is not "playing favorites," but rather "facing economic reality." 31 She also found it reasonable for the City to exempt the casino because the great majority of its patrons were not Evansvillians, but rather were outsiders. ${ }^{32}$

Steiler goes further than prior cases in its clear focus on the "inherent characteristics" aspect of equal privileges and immunities analysis. ${ }^{33}$ The Indiana Supreme Court's only prior focus on this aspect of the analysis came in Humphreys v. Clinic for Women, which analyzed state restrictions on Medicaid funding for abortions and concluded that two unequally treated classes were "virtually indistinguishable" from one another and " $[\mathrm{t}] \mathrm{o}$ the extent there is a distinction, it is too insubstantial to be sustained by the State's justification." 34

Steiler's analysis also is similar to the analysis Indiana courts apply under the special laws clause in article 4, section $23 .{ }^{35}$ In those cases, courts reject special laws under the constitutional text ("where a general law can be made applicable, all laws shall be general, and of uniform application throughout the State") ${ }^{36}$ unless special circumstances justify a statute that applies in only one location. ${ }^{37}$ The Steiler analysis seems similar: unless there is something inherently different about the unequally treated class, and the unequal treatment is based on that inherent difference, the statute or ordinance expressing the unequal treatment

\section{Id. at 1279 .}

29. Id.

30. Id. at 1280 .

31. Id.

32. Id. at 1282 .

33. Id. at 1269.

34. Humphreys v. Clinic for Women, 796 N.E.2d 247, 258 (Ind. 2003).

35. The article 4, section 23 analysis applies only after a court determines that a special law is not expressly forbidden by article 4 , section 22 , which lists sixteen categories of special laws that are automatically impermissible.

36. InD. CONST. art. $4, \S 23$.

37. Compare City of S. Bend v. Kimsey, 781 N.E.2d 683 (Ind. 2003) (statute invalid because no special circumstances) and Alpha Psi Chapter v. Auditor of Monroe Cnty., 8491131 (Ind. 2006) (same), with Hoovler v. State, 668 N.E.2d 1229 (Ind. 1996) (statute valid because justified by special circumstances) and Ind. Gaming Comm'n v. Moseley, 643 N.E.2d 296 (Ind. 1994) (same). 
violates article 1 , section $23 .^{38}$

Stieler provides new and useful guidance on how to advocate using the equal privileges and immunities clause and how it differs from the federal equal protection clause. It illustrates one of the few times when article 1, section 23 has been applied to reach a result more restrictive of legislative authority than the federal constitution. ${ }^{39}$ There seems to be little doubt that the Evansville ordinance would withstand a federal equal protection challenge - the Common Council's economic rationale would pass the federal "rational basis" test. ${ }^{40}$

But it does not withstand state constitutional scrutiny because of the "inherent characteristics" requirement, which is a unique element in the Indiana constitutional analysis. ${ }^{41}$ The legislative classification must be based on some inherent difference between the classes to withstand equal privileges and immunities analysis. ${ }^{42}$ While this analysis will often produce the same result as an equal protection inquiry, it sometimes will produce a different outcome.

In another article 1, section 23 case, Hucker v. State, the court of appeals rejected a claim that the statute criminalizing driving after having ingested a schedule I or II substance violates the equal privileges and immunities clause. ${ }^{43}$ Hucker argued that the statute violated the clause because it treated all schedule I and II substances identically, even though different substances affect people differently, especially when ingested in varying quantities. ${ }^{44}$ The court concluded that it is reasonable to treat all persons identically who ingest substances that impair their driving skills. ${ }^{45}$

\section{EDUCATION ${ }^{46}$}

In McIntire v. Franklin Township Community School Corp., a parent sued her children's school, challenging fees the school assessed for a locker, school

38. Stieler, 2 N.E.3d at 1269.

39. Section 23 has been used to invalidate statutes in only a few cases where the statute was not also invalid under the Equal Protection Clause. See, e.g., Humphreys, 796 N.E.2d at 247; Martin v. Richey, 711 N.E.2d 1273 (Ind. 1999).

40. FCC v. Beach Commc'ns, Inc., 508 U.S. 307, 313-14 (1993) (holding that economic "legislative judgment virtually [is] unreviewable, since the legislature must be allowed leeway to approach a perceived problem incrementally").

41. See Stieler, 2 N.E.3d at 1269.

42. See id.; Collins v. Day, 644 N.E.2d 72 (Ind. 1994).

43. Hucker v. State, 4 N.E.3d 797, 798 (Ind. Ct. App. 2014).

44. Id. at 800 .

45. Id.

46. During the survey period, the court of appeals decided Hoagland v. Franklin Township Community School Corp., 10 N.E.3d 1034 (Ind. Ct. App. 2014), trans. granted, 27 N.E.3d 737 (Ind. 2015), aff'd ruling that a school's decision to discontinue providing bus transportation to its students - while contracting with a private company to provide bus services to its students for a fee-violated the education clause, article 8, section 1. The Indiana Supreme Court granted transfer, vacating that opinion, and its decision likely will be reported in next year's article. 
newspaper, school activities, identification cards, technology, and textbook rental, alleging that each of these violated the students' right to "a general and uniform system of Common Schools, wherein tuition shall be without charge, and equally open to all." ${ }^{\prime 7}$ The trial court granted summary judgment to the school, ruling that the claim had to be dismissed because the parent had not filed a notice of tort claim and because there was no legal basis for the parent's claim for damages. ${ }^{48}$

The Indiana Court of Appeals reversed the portion of the judgment requiring notice of tort claim. ${ }^{49}$ Because the parent was asserting a constitutional claim, not a tort claim, she was not required to go through the notice of tort claim process. ${ }^{50}$ The Tort Claims Act applies only to "a claim or suit in tort."

The court of appeals affirmed dismissal of the claim for damages, however. ${ }^{52}$ The court ruled that "there is no right of action for monetary damages under the Indiana Constitution." 53 If the parent prevails, she will not have to pay the fees she alleges to be unlawful, and she can obtain declaratory and injunctive relief. ${ }^{54}$ Her claim that depriving her of damages would expose "a right without a remedy" is therefore incorrect, the court ruled.$^{55}$ Because the parent claimed only monetary relief in this case, however, the court of appeals affirmed dismissal of the case. ${ }^{56}$

\section{SPEECH}

In Brewington v. State, ${ }^{57}$ the Indiana Supreme Court held that Indiana's constitutional protection of free speech requires evidence of a defendant's subjective intent to cause the target of the speech to fear for his or her safety to sustain a conviction for criminal intimidation. ${ }^{58}$ The court also reapplied its holding that Indiana's constitutional free speech shield requires application of a rigorous "actual malice" standard for prosecution of reputational attacks and cautioned prosecutors against bringing criminal defamation charges given the difficulty of proving actual malice. ${ }^{59}$

47. McIntire v. Franklin Twp. Cmty. Sch. Corp., 15 N.E.3d 131, 133 (Ind. Ct. App. 2014), trans. denied 15 N.E.3d 131 (Ind. 2015); IND. ConsT. art. 8, § 1.

48. McIntire, 15 N.E.3d at 133.

49. Id. at 137 .

50. Id. at 136-37.

51. IND. CODE § 34-13-3-1 (2015).

52. McIntire, 15 N.E.2d at 137.

53. Id.

54. Id.

55. Id.

56. Id. at 137-38.

57. 7 N.E.3d 946 (Ind. 2014). In what appears to be an increasing practice, the court held oral argument before deciding whether to accept transfer. See id. at 955.

58. Id. at 964 .

59. Id. at 962 . 
The court noted that its ordinary standard of review (only considering evidence supporting a conviction and affirming unless no reasonable fact-finder could find the necessary elements proven beyond a reasonable doubt) did not apply because the issue involved constitutional free speech rights. ${ }^{60}$ Thus, because the question of constitutional protection for speech turned on issues of state-of-mind, the court performed an independent examination of the record to assure itself that the conviction did not intrude "on the field of free expression." 61

The court recognized that the First Amendment to the United States Constitution requires convictions based on "true threats" to rest on evidence showing beyond a reasonable doubt that an ordinary and reasonable recipient, familiar with the statement's context, would interpret the statement as an expression of intent to commit unlawful violence against someone. ${ }^{62}$ Determining whether a statement is a "true threat," and thus outside the stringent "actual malice" standard, involves a purely objective test that looks at whether the recipient could have regarded the statement as a threat and disregards the threatener's state of mind. ${ }^{63}$ Yet resting on its 1999 decision in Journal Gazette Co. v. Bandido's, the court accepted Brewington's request to go beyond what is required by the First Amendment and held that Indiana's constitutional free speech protections required analysis of whether he actually intended to place his targets in fear of their safety. ${ }^{64}$ Thus, "true threat" analysis under Indiana law requires two elements: (1) the speaker intended his or her communication to cause the target to fear for his or her safety, and (2) the communication is likely to cause such fear in a reasonable person similarly situated to the target. ${ }^{65}$

Yet despite this heightened analysis, the court found that the State presented sufficient evidence that Brewington intended to place his targets - a judge and a doctor - in fear of their safety. ${ }^{66}$ As to the judge, the court found it significant that Brewington published the judge's home address. ${ }^{67}$ That publication "could only have intended ... as a hint to the Judge that Defendant's campaign would not stop with mere criticism, but would instead jeopardize his family's safety in

60. Id. at 955 .

61. Id. (quoting J-Gazette Co. v. Bandido's, Inc., 712 N.E.2d 446, 455 (Ind. 1999)).

62. Id. at 964 (quoting Virginia v. Black, 538 U.S. 343 (2003)).

63. Id.

64. Id. By recognizing that the court's review would focus on Brewington's state of mind, the court adopted the requirement that the State must prove the defendant's subjective intent in proving criminal intimidation. The United States Supreme Court is considering that issue in Elonis v. United States, with a decision expected later this term. See Elonis v. United States, SCOTUSBLOG, http://www.scotusblog.com/case-files/cases/elonis-v-united-states/ (last visited May 14, 2015), archived at http://perma.cc/6WXH-UZVS. The United States Supreme Court granted the Petition for a writ of certiorari in Elonis on June 16, 2014, just over a month after the Indiana Supreme Court decided Brewington on May 1, 2014.

65. Brewington, 7 N.E.3d at 964.

66. Id. at 966 .

67. Id. 
their own home." ${ }^{68}$ But most significantly, Brewington made statements in a letter that he "would argue that" what "[s]ome would argue . . . appears threatening . . . is a promise" to "hold everyone accountable for any unethical and/or illegal conduct in matters dealing with my children." ${ }^{69}$ This language was "legitimately menacing in view of" Brewington's recent violent and uncontrolled courtroom behavior, psychological disturbance and dangerousness diagnosis, veiled references to arson and firearms skill, and longstanding hostile expressions towards the judge. ${ }^{70}$

The court found that Brewington intended to threaten the doctor based on Internet publications where he strongly implied, or even directly expressed, his intent to issue threats. ${ }^{71}$ Brewington also demonstrated in an Internet post that he knew where the doctor lived and that he knew that his statements were in fact intimidating the doctor to the point that the doctor sought court protection. ${ }^{72}$ Based on these facts, the court found that the context demonstrated that Brewington "not only knew that his victims would be placed in fear, but purposefully intended that result." 73

The court then addressed whether Brewington could be convicted of intimidating the judge and the doctor under a provision in the statute defining "threat" as exposing the threatened person to "hatred, contempt, disgrace, or ridicule" or "falsely harming the person's credit or business reputation." Because this definition of threat closely tracked common-law defamation claims, the court analyzed the convictions under the same constitutional free speech lens applicable in civil defamation cases. ${ }^{75}$

The court found that under federal constitutional analysis, Brewington's conviction for intimidation of the judge under the defamation provision could not stand because of the absence of any evidence showing that Brewington subjectively thought what he was saying was actually false. ${ }^{76}$ The "actual

68. Id. at 965

69. Id. at 967.

70. Id. The court also found that the threats directed at the judge would cause a reasonable person to fear for his or her safety. Id. at 970.

71. Id. at 968 .

72. Like the trial judge, the court found that the threats directed at the doctor would cause a reasonable person to fear for their safety. Id. at 971 .

73. Id. at 965 .

74. IND. CODE $\S 35-45-2-1(c)(6)-(7)$ (2015). Because this case was resolved on another issue, as described above, the state constitutional discussion described in the three paragraphs after this footnote could be regarded as dictum.

75. Brewington, 7 N.E.3d at 958-59.

76. Id. at 961 . Brewington's statements included allegations that the judge had conflicts of interest; conducted himself in a willful, malicious, and premeditated manner; robbed Brewington of his parenting rights as a revenge for Brewington's fight against injustice; irreparably damaged Brewington's children via "Court mandated child abuse" by illegally eliminating the children's father from their lives to serve "the Court's self-interest"; and used "child abducting tactics" in issuing a divorce decree. Id. at 959-60. 
malice" standard from New York Times v. Sullivan ${ }^{77}$ forbids punishing defamatory falsehoods related to public officials' official conduct without evidence that the speaker knew that the statement was false or made the statement with reckless disregard of its falsity. ${ }^{78}$ The State failed to introduce any evidence that Brewington made his statements - although defamatory per se since the statements imputed judicial misconduct - with any doubt as to the statement's truth. ${ }^{79}$ Thus, the First Amendment to the United States Constitution prohibited the use of the statements as the basis for civil or criminal liability. ${ }^{80}$

Similarly, yet on separate grounds under the Indiana Constitution, the court found that Brewington's conviction for intimidation of the doctor could not stand. ${ }^{81}$ Based on the Journal Gazette Co. v. Bandido's decision, the court found that the doctor's status as a non-public figure did not diminish Brewington's constitutional free speech rights. ${ }^{82}$ Instead, because Brewington was speaking on a manner of public interest, ${ }^{83}$ the actual malice standard (applicable to the statements against the judge under the First Amendment) also applied to the statements against the doctor under the Indiana Constitution. ${ }^{84}$

The court's holding that Indiana law requires proof of subjective intent for a statement to constitute a "true threat" is significant for two reasons. First, and most obviously, the First Amendment did not compel this result — at least not yet. Regardless of what the United States Supreme Court decides in Elonis v. United States ${ }^{85}$ Indiana law will require evidence that threateners intended to place their targets in fear. ${ }^{86}$ Second, the decision does not analyze why Indiana law requires this additional step. ${ }^{87}$ The decision to require subjective intent rests entirely on

77. 376 U.S. 254,285 (1964).

78. Brewington, 7 N.E.3d at 959.

79. Id. at 961 .

80. Id. The court also found that Defendant's statements were borderline hyperbolic akin to the "drunken incestuous rendezvous" at issue in Hustler Magazine, Inc. v. Falwell, 485 U.S. 46, 57 (1988). Although the Indiana Supreme Court found that Brewington sincerely believed the truth of his statements, the court doubted readers would believe that the judge actually kidnaps and beats children. Brewington, 7 N.E.3d at 961. The Indiana Supreme Court typically leaves such questions of fact for a jury. Yet the court's more searching standard of review given the conviction's constitutional implications, allowed the court to find that the evidence of Brewington's guilt was not beyond a reasonable doubt. $I d$.

81. Brewington, 7 N.E.3d at 962.

82. Id.

83. Id. The court noted that it was assuming arguendo that Brewington's statements against the doctor were public to the extent that the statements alleged a psychologist's abuse of trust to give corrupt expert testimony that if true, would be a matter of public concern. $I d$.

84. Id.

85. See Elonis v. United States, SCOTUSBLOG, http://www.scotusblog.com/case-files/cases/ elonis-v-united-states/ (last visited May 14, 2015), archived at http://perma.cc/6WXH-UZVS.

86. See Brewington, 7 N.E.3d at 962.

87. Indeed, the decision does not even cite the Indiana constitutional provisions protecting free speech, article 1 sections 9 and 10. For more on the Elonis decision, see supra note 64. 
the fifteen-year-old decision addressing civil defamation in Bandido's. ${ }^{88}$ The absence of any analysis may leave this requirement open to further judicial interpretation in cases where evidence of the speaker's subjective intent is not directly available as it was for Brewington, given his written pronouncements. ${ }^{89}$

\section{SEPARATION OF POWERS}

The court of appeals held in Whitesitt v. Town of Knightstown that courts of inferior and limited jurisdiction, created under authority of the General Assembly, conferred on a municipality, are not subject to separation of powers protection under the Indiana Constitution. ${ }^{90}$ The Town of Knightstown established a town court in 1970 under a statutory grant of authority from the General Assembly. ${ }^{91}$ The town abolished the court due to revenue shortfalls and the court's judge sued the town alleging statutory and constitutional violations. ${ }^{92}$

The court of appeals recognized that State v. Monfort ${ }^{93}$ held that the General Assembly could not abolish a court in the middle of a judge's term due to the separation of powers doctrine even though article VII, section 1, grants the General Assembly authority to abolish courts that are not constitutionally mandated. ${ }^{94}$ Yet the court of appeals distinguished Monfort based on the town court's status as an inferior court and limited in jurisdiction. ${ }^{95}$ Separation of powers was not at issue, the court held, because that doctrine only applies to state governments and state officers, not municipal or local governments. ${ }^{96}$

\section{SEARCH AND SEIZURE}

In Guilmette v. State, the Indiana Supreme Court rejected a claim that seizure of DNA evidence violated the Indiana Constitution. ${ }^{97}$ Guilmette was visiting a friend's home, and after the friend and another co-worker, Piechocki, went to sleep, Guilmette stole Piechocki's money and car keys; he used the car to drive to a store where he shoplifted. ${ }^{98}$ Piechocki was beaten to death on the same night. ${ }^{99}$

88. Notably, Justices Dickson and Rucker, the two remaining justices on the court at the time of Bandido's, concurred without comment in Brewington.

89. See Brewington, 7 N.E.3d at 962.

90. Whitesitt v. Town of Knightstown, 998 N.E.2d 729 (Ind. Ct. App. 2013).

91. Id. at 730 .

92. Id.

93. 723 N.E.2d 407 (Ind. 2000).

94. Whitesitt, 998 N.E.2d at 733. The Indiana Constitution mandates the supreme court, court of appeals, and circuit courts. Superior, city, and town courts are not constitutionally mandated but are created by statute.

95. Id.

96. Id.

97. Guilmette v. State, 14 N.E.3d 38 (Ind. 2014).

98. Id. at 39.

99. Id. 
Police initially arrested Guilmette for theft of Piechocki's keys and money, and they confiscated his clothing as part of the booking process at the time of arrest. ${ }^{100}$ Scientific analysis of the clothing showed traces of Piechocki's blood and DNA and, at that point, police also charged Guilmette with Piechocki's murder. ${ }^{101}$

Guilmette moved to suppress the DNA evidence, arguing that police should have obtained a separate warrant before running DNA tests on his clothing. ${ }^{102}$ The motion was denied, Guilmette was tried and convicted, and he raised the same issue on appeal. ${ }^{103}$ Guilmette argued that admission of the DNA evidence violated article 1 , section 11 because he was arrested for one crime - theft — and the evidence was used against him for another crime-murder-making the seizure of his clothing an improper search incident to arrest. ${ }^{104}$ As required under the Indiana Constitution, the supreme court looked at this issue through the lens of the reasonableness of law enforcement conduct. ${ }^{105}$ Applying the Litchfield factors, the court balanced "1) the degree of concern, suspicion, or knowledge that a violation has occurred, 2) the degree of intrusion the method of the search or seizure imposes on the citizen's ordinary activities, and 3) the extent of law enforcement needs." 106 The court noted that admitting evidence such as that at issue in this case raised no Fourth Amendment issue. ${ }^{107}$

The court, in a unanimous opinion, came to the same result under the Indiana Constitution. ${ }^{108}$ On the Litchfield factors, it reasoned that (1) police had a strong suspicion Guilmette was involved in Piechocki's death; (2) the intrusion on his daily activities was minimal; and (3) although there was no exigency, it would be cumbersome to require a warrant before testing a piece of evidence police already had lawfully seized. ${ }^{109}$ It did not matter, the court ruled, that the evidence was used to prosecute a different crime than that for which Guilmette had been arrested: "Guilmette was arrested and his clothing seized pursuant to standard police procedure. Any subsequent search of that clothing, regardless of the means used or the evidence found, was therefore permissible as a search incident to a lawful arrest." "110

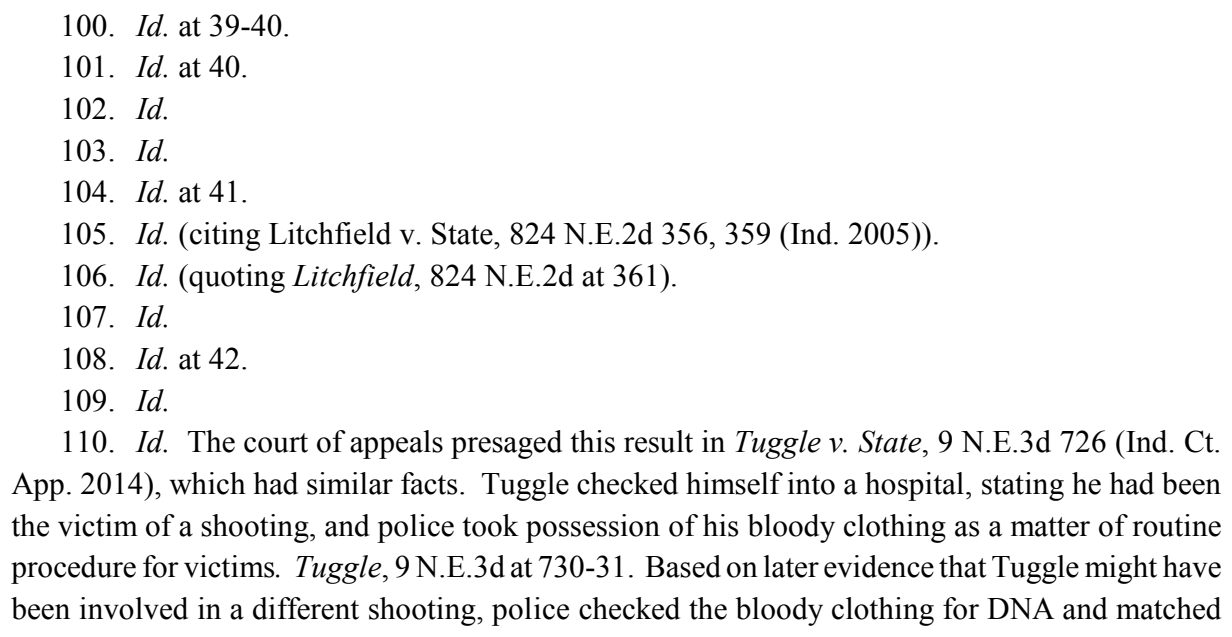
App. 2014), which had similar facts. Tuggle checked himself into a hospital, stating he had been the victim of a shooting, and police took possession of his bloody clothing as a matter of routine procedure for victims. Tuggle, 9 N.E.3d at 730-31. Based on later evidence that Tuggle might have been involved in a different shooting, police checked the bloody clothing for DNA and matched 
The supreme court decided two other section 11 cases during the survey period. ${ }^{111}$ It upheld a traffic stop based on an officer's perception that the driver crossed the white fog line twice in a brief period in Robinson v. State. ${ }^{112}$ The court of appeals had reversed the trial court's finding of probable cause for the stop based in part on video shot from the police vehicle, but the supreme court credited the officer's testimony, which the court of appeals found to be inconsistent with the video. ${ }^{113}$ In rejecting reliance on the video, the court stated, "[w]hile technology marches on, the appellate standard of review remains constant[,]" and declined to "reweigh the evidence." "114 Austin v. State also involved a traffic stop, this time involving singular circumstances: a state trooper stopped a semi-trailer that was configured in an unusual manner. ${ }^{115}$ During the stop, the trooper found that the driver's log and bills of lading contained gaps and errors, and the driver seemed to be traveling away from the destination in his manifest. ${ }^{116}$ The driver declined to permit a search, and the officer allowed him to drive on. ${ }^{117}$ Other police units monitored the truck and stopped him again after he committed traffic violations. ${ }^{118}$ Officers used a drug dog, which alerted for the presence of illegal drugs. ${ }^{119}$ Police obtained a warrant to search the trailer and found forty pounds of cocaine in hidden compartments. ${ }^{120}$ The driver moved to suppress the results of the search, but the supreme court ruled the search valid under article 1, section 11, based on Litchfield balancing. ${ }^{121}$ The driver conceded the validity of the stop, but argued that he was detained too long and that the stop was pretextual. ${ }^{122}$ The court ruled that anomalies in the driver's log and bills of lading, his inconsistent answers to police questions, and the driver's history of drug involvement (which officers learned by consulting a database) provided adequate support for the search. ${ }^{123}$

it to blood on a murder victim's body. Id. at 731. The court affirmed the search under the Indiana Constitution, finding that there was no intrusion involved in taking the clothing (which was already bagged by the hospital) and high law enforcement need. Id. at 735-36.

111. See Robinson v. State, 5 N.E.3d 362 (Ind. 2014); see also Austin v. State, 997 N.E.2d 1027 (Ind. 2013).

112. Robinson, 5 N.E.3d at 362.

113. $I d$. at 365 .

114. Id. Justice Rucker dissented, concluding that the court of appeals "got it exactly right" because, as he understood the testimony, there was no evidence that the car actually left the roadway and therefore no probable cause for a stop. Id. at 369-70.

115. Austin, 997 N.E.2d at 1032.

116. $I d$.

117. $I d$.

118. $I d$.

119. Id. at 1033 .

120. Id.

121. Id. at 1035 .

122. Id. at 1034 .

123. Id. at 1035-37. The court of appeals also analyzed a variety of traffic stop seizures under article 1, section 11, holding that some stops were valid: Veerkamp v. State, 7 N.E.3d 390 (Ind. Ct. 
The court of appeals also decided several section 11 cases during the survey period. In a case of first impression, Gyamfi v. State, the court rejected the applicability of the inevitable discovery rule in section 11 cases, although the principle is available under the Fourth Amendment. ${ }^{124}$ Gyamfi was charged with credit card fraud in two different counties. In one county, he asserted-and the State agreed - that he had been illegally searched. ${ }^{125}$ He moved to suppress evidence in the second county as fruit of the poisonous tree. ${ }^{126}$ The court rejected the State's argument that Gyamfi's crime would inevitably have been discovered, which vitiates the illegal search under the Fourth Amendment. ${ }^{127}$ "Our supreme court has previously held that 'our state constitution mandates that the evidence found as a result of [an unconstitutional] search be suppressed" "and "we are not inclined to adopt the inevitable discovery rule as part of Indiana constitutional law in light of our supreme court's firm language." 128 The court also rejected the doctrine of attenuation, which it previously had ruled inapplicable to section 11 claims. ${ }^{129}$

In a case presenting a related issue, Blankenship v. State, the court of appeals applied the good faith exception to the warrant requirement to an Indiana constitutional claim for unlawful search. ${ }^{130}$ A hotel manager invited police to bring a drug dog to the hotel because the manager suspected illegal activity, and the dog alerted on one of the rooms. ${ }^{131}$ Officers obtained a search warrant and found methamphetamine and other drugs and paraphernalia. ${ }^{132}$ The trial court denied a motion to suppress, and Blankenship was convicted on several drug charges. ${ }^{133}$ The court assumed, but declined to decide, that the warrant lacked probable cause because officers had no specific reason to deploy the drug dog on

App. 2014) (traffic stop for "excessive smoke" was based on probable cause, and arrest for operating while intoxicated was valid); Richard v. State, 7 N.E.3d 347 (Ind. Ct. App. 2014) (affirming warrantless search of passenger after drug dog alerted on passenger side of car at proper traffic stop); Croom v. State, 996 N.E.2d 436 (Ind. Ct. App. 2013) (investigatory stop based on temporary license plate that should have been in the state's database but wasn't was based on reasonable suspicion, and arrest for driving without a license was valid); and one was not: Kroft v. State, 992 N.E.2d 818 (Ind. Ct. App. 2013) (stop for failure to have two working tail lamps was improper when the allegedly deficient tail lamp had only a dime-sized hole emitting white light but otherwise emitted red, reversing denial of motion to suppress).

124. Gyamfi v. State, 15 N.E.3d 1131, 1137-38 (Ind. Ct. App. 2014).

125. Id. at 1134 .

126. Id. at 1136.

127. Id. at $1137-38$.

128. Id. at 1138 .

129. Id. at 1137 (citing Trotter v. State, 933 N.E.2d 572 (Ind. Ct. App. 2010)). Judge Bradford concurred in part and concurred in result, reasoning that the inevitable discovery rule could apply in certain circumstances but was not satisfied in this case. Id. at 1138.

130. Blankenship v. State, 5 N.E.3d 779, 784 (Ind. Ct. App. 2014).

131. Id. at $780-81$.

132. Id. at 781 .

133. Id. 
that particular hallway of the hotel; but the court validated the search regardless of that assumption because the police acted in good faith when they relied on the search warrant. ${ }^{134}$

In McCowan v. State, a murder case, the defendant objected to the state obtaining his cell phone records, including text messages, pursuant to a warrant, and (without a warrant) cell phone records showing only the defendant's location. ${ }^{135}$ The court found that the cell phone records should not be suppressed under the Indiana Constitution. ${ }^{136}$ Applying the Litchfield factors, police had a high degree of suspicion that the defendant was at least acquainted with the victim and had knowledge where she might be; the degree of intrusion was minimal, involving only looking at cell phone records and not otherwise affecting the defendant; and the extent of law enforcement needs was great when the request was made because the victim had not been found and possibly was still alive. ${ }^{137}$

A juvenile sought to suppress evidence under section 11 in C.H. v. State, in which he had been judged delinquent for car theft charges. ${ }^{138}$ An individual reported her car stolen, and an officer in the neighborhood began looking for cars fitting its description; he stopped one such car, and four juveniles ran away from it. ${ }^{139}$ The officer reported their general description by radio, and another officer one block away stopped two youths fitting the description. ${ }^{140}$ Another officer viewed the surveillance video from a service station where the youths had abandoned the car, and he identified C.H., one of the youths who had been stopped, based on the video. ${ }^{141}$ The court of appeals ruled that the identification did not have to be suppressed under section 11 based on Litchfield balancing, which led to a finding that the officer's conduct was reasonable. ${ }^{142}$ First, there was a high degree of concern that a violation had occurred. ${ }^{143}$ Second, the degree of intrusion was minimal because the youths were detained for only a short time until an identification could be made. ${ }^{144}$ Third, law enforcement need was high in the context of investigation of suspects fleeing a stolen vehicle. ${ }^{145}$

134. Judge Baker concurred, declining to assume that there was no probable cause for the drug dog deployment because police had been invited to the premises by the hotel's manager for the express purpose of searching for drugs. $I d$. at 785-86.

135. McCowan v. State, 10 N.E.3d 522, 529-30 (Ind. Ct. App. 2014).

136. Id. at 525 .

137. Id. at 533-35.

138. C.H. v. State, 15 N.E.3d 1086 (Ind. Ct. App. 2014).

139. Id. at 1089.

140. Id. at 1090 .

141. Id.

142. Id. at 1093 .

143. Id.

144. Id.

145. Id. 


\section{Double JEOPARDY}

The Indiana Supreme Court found a state double jeopardy violation in Cross v. State, in which the defendant was convicted of cocaine dealing, enhanced for his use or possession of a firearm, and felony carrying a handgun without a permit. ${ }^{146}$ The appeal arose in the context of a post-conviction relief proceeding. ${ }^{147}$ The court applied the state double jeopardy rule from Richardson v. State, which states that "two or more offenses are the same offense in violation of Article 1, Section 14 of the Indiana Constitution, if, with respect to either the statutory elements of the challenged crimes or the actual evidence used to convict, the essential elements of one challenged offense also establish the essential elements of another challenged offense." 148 The court found a double jeopardy violation because the conviction for carrying a firearm and the sentence enhancement for use or possession of a firearm while dealing in a controlled substance were based on precisely the same act, violating double jeopardy principles. ${ }^{149}$

In similar circumstances, the court of appeals vacated a cocaine possession conviction in Bennett v. State, because the cocaine that supported the conviction was the same cocaine that supported Bennett's dealing conviction, violating double jeopardy provisions (as the state conceded) because the same evidence was used to support two separate convictions. ${ }^{150}$ In C.H. v. State, the court of appeals also vacated a juvenile adjudication for unlawful entry of a motor vehicle because the adjudication was supported by precisely the same evidence used to adjudicate the juvenile delinquent for criminal trespass. ${ }^{151}$ But in Montgomery v. State, the court rejected a double jeopardy claim by a defendant who was tried for failure to register as a sex offender in two different counties. ${ }^{152}$ The defendant claimed that there was a single act of failing to register, and punishing him twice for that conduct would constitute double jeopardy. ${ }^{153}$ But the court of appeals ruled that he had separate statutory duties to register in his county of residence and, when he moved, in the new county of residence. ${ }^{154}$ Having done

146. Cross v. State, 15 N.E.3d 569, 570 (Ind. 2014).

147. Id.

148. Richardson v. State, 717 N.E.2d 32, 49 (Ind. 1999).

149. Cross, 15 N.E.3d at 573. Although the court quoted the Indiana Constitution, it also noted that Indiana's double jeopardy jurisprudence includes a series of rules and statutory construction and common law principles that supplement constitutional double jeopardy protections, including a rule prohibiting conviction and punishment for an enhancement of a crime for the very same behavior as another crime for which the defendant has been convicted and punished. Id. at 571 (citing Miller v. State, 790 N.E.2d 437, 439 (Ind. 2003) (quoting Richardson, 717 N.E.2d at 56 (Sullivan, J., concurring))).

150. Bennett v. State, 5 N.E.3d 498, 515 (Ind. Ct. App. 2014).

151. C.H. v. State, 15 N.E.3d 1086, 1094-95 (Ind. Ct. App. 2014).

152. Montgomery v. State, 14 N.E.3d 76 (Ind. Ct. App. 2014).

153. Id. at 79 .

154. Id. at 80 . 
neither, the court ruled, he violated the law twice and could be convicted for both violations. ${ }^{155}$

\section{Right to COMPLEte Justice}

The Indiana Supreme Court held in Inman $v$. State that the cumulative effect of trial court errors did not deny a criminal defendant - sentenced to life in prison without possibility of parole - his right to due course of law under article 1, section 12 of the Indiana Constitution. ${ }^{156}$ Citing Hubbell v. State, the court recognized that it has assumed previously, for the sake of argument, that a circumstance could exist where the totality of trial errors could justify reversal even where the individual errors are harmless in isolation. ${ }^{157}$ The principle - that a set of constitutional errors, harmless in isolation, but in totality a denial of complete justice - continues to operate in theory.

The court found on direct appeal that although the trial court (1) erred in allowing the State to refer to Inman as a suspect in another crime, (2) erroneously instructed the jury that the "spirit of our criminal law would not be fostered" if a "defendant could not be convicted of robbing a man he had just killed," and (3) allowed the jury hear the court refer to a "criminal spree," those errors were not sufficiently cumulative to deny Inman a fair trial. ${ }^{158}$ Instead, the court found that Inman was "entitled to a fair trial, not a perfect trial." 159 The errors were isolated — not pervasive — and at best, minor. ${ }^{160}$

\section{SELF-INCRIMINATION}

The Indiana Court of Appeals affirmed in State v. Banks the suppression of a murder confession that followed an inadequate Miranda warning to a seriously mentally ill suspect who was involuntarily medicated and restrained during an interrogation. ${ }^{161}$ After finding that the record revealed inadequate Miranda advice by the interrogator, the court analyzed whether coercive police activity is a prerequisite to establishing a violation of article 1, section 14 of the Indiana Constitution. ${ }^{162}$ The State maintained that Banks failed to demonstrate confusion, indicated that he understood his rights, and validly waived those rights before his confession. ${ }^{163}$

Based on Justice DeBruler's concurring opinion in Linthicum v. State, ${ }^{164}$ Banks argued that under Indiana's Constitution, unlike the United States

155. Id.

156. Inman v. State, 4 N.E.3d 190 (Ind. 2014).

157. Id. at 203.

158. Id. at $198-204$.

159. Id. at 203 (quoting Myers v. State, 887 N.E.2d 170, 175 (Ind. Ct. App. 2008)).

160. Id.

161. State v. Banks, 2 N.E.3d 71, 83-84 (Ind. Ct. App. 2014).

162. Id. at 80-83.

163. Id. at 79 .

164. 511 N.E.2d 1026, 1031 (Ind. 1987). 
Constitution, coercive police activity is not a prerequisite to finding a confession involuntary. ${ }^{165}$ The State maintained that the Indiana Supreme Court's opinion in Ajabu v. State suggested otherwise. ${ }^{166}$ The court found that Ajabu did not hold that coercive police activity serves as a prerequisite to establish a violation of article 1, section 14. ${ }^{167}$ Instead, Ajabu recognized that waivers must be informed and that intelligent and voluntary waivers can be given only where the individual is not incompetent. ${ }^{168}$ The court emphasized that the fact that the defendant is mentally ill will not render his statements inadmissible per se. ${ }^{169}$

\section{SPEEDY TRIAL}

In McClellan v. State, ${ }^{170}$ the Indiana Court of Appeals remanded an interlocutory appeal because the trial court failed to apply the appropriate federal and state constitutional speedy trial analytical framework in denying a motion to dismiss a charge of operating a vehicle while intoxicated. ${ }^{171}$ The two year and five month delay between filing charges and McClellan's arrest was attributable to the State's issuance of summons and warrants to an outdated address. ${ }^{172}$ The court recognized that a post-accusation delay lasting more than a year is presumptively prejudicial. ${ }^{173}$ The cause of the delay — an outdated address-was attributable to the State because McClellan was on home detention when the court issued summons and warrants. ${ }^{174}$ The court noted that only a reasonable effort by the State is required to locate a defendant — otherwise an arrestee would be incentivized to "hide out" for a year. ${ }^{175}$ The court set that concern aside in McClellan's case, however, because the State had actual notice of McClellan's address given his home detention under state court supervision. ${ }^{176}$ Yet McClellan's failure to assert his speedy trial rights two months after he first had the opportunity neutralized this factor. ${ }^{177}$ The court remanded to the trial court to balance whether he suffered sufficient prejudice by the delay. ${ }^{178}$

165. Banks, 2 N.E.3d at 79-82.

166. Id. at $80-83$.

167. Id. at 83 .

168. Id. at 82-83 (quoting Michigan v. Mosley, 423 U.S. 96, 109 (1975) (White, J. concurring)).

169. Id. at 83 .

170. 6 N.E.3d 1001 (Ind. Ct. App. 2014).

171. Id. at 1005-06.

172. Id. at 1005 .

173. Id.

174. Id. at 1005-06.

175. Id. at 1005 n.6.

176. Id. at 1005-06.

177. Id. at 1006 .

178. Id. The Indiana Supreme Court also vacated a child molestation conviction in Logan v. State, 16 N.E.3d 953 (Ind. 2014) because of violations of the United States and Indiana constitutional rights to a speedy trial. The court did not apply any separate state constitutional 


\section{Right to Be PRESENT}

In Calvert v. State, the court of appeals reversed the conviction of an Army private because the trial court tried him in absentia while he was serving in Afghanistan. ${ }^{179}$ Under Lampkins $v$. State, a defendant has a right under article 1, section 13 and the Sixth Amendment to be present at all stages of trial. ${ }^{180}$ Calvert's deployment to Afghanistan justified his trial's continuance. ${ }^{181}$ "The State of Indiana cannot compel a defendant's presence for judicial proceedings, while at the same time, the United States compels his absence for active duty in military service overseas." 182 But the court rejected his claim, based in double jeopardy, that he could not be retried. ${ }^{183}$ Calvert argued that a prosecutor's misrepresentations to the trial court that the defendant enlisted in the military to avoid prosecution and that defense counsel sought a continuance a day before the trial date violated double jeopardy prohibitions. ${ }^{184}$ The court held that retrial of a defendant is generally permissible when the conviction is reversed on grounds other than sufficiency of the evidence. ${ }^{185}$

analysis; it found the speedy trial violation after applying federal analysis, but stated that the delay violated both the federal and state constitutions.

179. Calvert v. State, 14 N.E.3d 818 (Ind. Ct. App. 2014).

180. Id. at 821 (citing Lampkins v. State, 682 N.E.2d 1268, 1273 (Ind. 1997)).

181. Id.

182. $I d$.

183. Id. at 822 .

184. Id. at 822-23.

185. Id. at 823 . 